\title{
The Role of the N.Z. Yartsev in the Development of Musical and Theatrical Life of Pre-Revolutionary Minusinsk
}

\author{
Irina Efimova \\ Department of History of Music \\ Krasnoyarsk State Institute of Arts \\ Krasnoyarsk, Russia \\ E-mail: acamus.cabinet@mail.ru
}

\author{
Tatyana Kuzmina \\ Department of History of Music \\ Krasnoyarsk State Institute of Arts \\ Krasnoyarsk, Russia \\ E-mail: tatiankomuz@mail.ru
}

\begin{abstract}
The article «N.Z. Yartsev - an outstanding figure of the artistic culture in Siberia» is devoted to Nicholay Zakharovich Yartsev, a prominent artist, who had a notable influence on the musical culture of Minusinsk in the 19th and 20th centuries. The article reveals the importance of the activities of N.Z. Yartsev for the artistic life of both the southern part of the Krasnoyarsk territory and the Siberian region in the whole on the basis of documentary and rare sources identified GAKK, the Minusinsk state archive, the Minusinsk museum of local history named after N.M. Martyanov, the Minusinsk Drama theater, as well as of a number of pre-revolutionary periodicals.
\end{abstract}

Keywords-history of musical culture; Krasnoyarsk region; Minusinsk; Literature and Music and Drama Society; Yartsev N.Z.; Minusinsk state archive; Minusinsk museum of local history by named N.M. Martyanov

\section{INTRODUCTION}

The interest of researchers to study the culture of the Siberian region of the Russian Federation has increased significantly around the end of the '80s of the 20th century. This is evidenced by the appearance of monographs devoted to the musical lives of Tomsk, Irkutsk, Chita, Krasnoyarsk, as well as similar works in other genres of research. Among them, there is a fundamental 3-volume work titled "The Musical culture of Siberia" (1997), prepared by a team of faculty and the staff of the Novosibirsk State Conservatory. It reflects the history of the musical life of large Siberian cities such as Irkutsk, Krasnoyarsk, Tomsk, Omsk, Tyumen, Barnaul, as well as of the Republic of Khakassia, Buryatia, Tuva [3].

However, until now, no proper attention is paid to the south of the Krasnoyarsk Territory - the Minusinsk District of the former Yeniseisk province. Lack of musicological research works about the cultural and the musical life of the region is largely led by fact. In 1930, a substantial part of the Minusinsk district was detached as the Khakass Autonomous Region, and although the number of Russian old residents in the area was considerable, the Khakass ethnic group, whose culture, respectively, appeared in the focus of researchers of a wide profile, was considered to be title one. At the same time, the problem of the formation of the academic culture, which goes back to the European tradition, especially established in Minusinsk, was on the periphery of the attention of scientists.

Consequently, special works about the musical and the theatrical life of Minusinsk, at least those of the musicological trend, are hitherto lacking. There is a separate chapter on the history of musical culture and musical education academic tradition in the Republic of Khakassia in the already mentioned multi-volume edition of "The Musical culture of Siberia." But it touches upon the history of the musical life of the region, starting with only the postrevolutionary period. The facts presented are of general nature.

The object of study is the musical theater of the prerevolutionary Minusinsk, the life and work of it brightest representative - Nicholay Zakharovich Yartsev.

The subject of research is the regional specificity of music and theater life in the South of the Krasnoyarsk Territory, revealed in the context of national and regional socio-cultural characteristics of the whole.

\section{FORMATION OF MUSICAL AND THEATRICAL LIFE OF THE PRE-REVOLUTIONARY MINUSINSK}

The value of the theater in the formation of cultural and musical life of any city cannot be overestimated. Thanks to its democratic and diverse literary and musical forms, theater resonated with a wide range of listeners. At the same time, it has always had an important and aesthetic-based task: to instill artistic and musical taste to the public, to reveal the power and beauty of classical masterpieces.

As it's known, the history of the secular theater in Russia dates back to 1672 , the year when the court of King Alexei Mikhailovich (1629-1676) staged theatrical performances accompanied by a small orchestra forces of foreign actors. The opening of the first public theater in Russia "Komedialnay horomina" dates back to 1702. In the beginning of the 18th century, they received the so-called school theaters were in widespread in Russia many educational institutions of Moscow, St. Petersburg. In the 
European part of the Russian state theater, the art spread quickly. It started from the 18th century and reached a high level of development during the 19th century, especially in the largest cities - St. Petersburg, Moscow, Saratov. At the turn of the 18th - 19th centuries, public professional theaters opened in Omsk, Barnaul, Irkutsk, Tomsk, Tobolsk.

The Krasnoyarsk Territory theatrical business has emerged much later. According to E.V. Prygun, the first information about the touring troupes of actors in the capital of the Yeniseisk province refer only to the 40's of the 19th century, and the city theatre management appeared only in the 70 of the same century [10, p. 218]. As the researcher, rightly observes is the "lateness" of the provincial capital in the development of theater art was due to the comparatively late extension of Krasnoyarsk as an economic, political and cultural center of the province. For the formation of the urban artistic and aesthetic environment, there needed to be a certain human contingent, interested and directly involved in shaping the cultural life of society (the patrons, the nobility, and so on). This was formed only after almost a century after the raids on the city from the Kyrgyz and Jungar rulers stopped.

In Minusinsk, the capital of the southern district of the Yeniseisk province, the formation of the intelligentsia began in 1830 - 1840 during the so-called "gold rush". The city, thanks to the flourishing of the gold, mining, became the center of attraction for the merchant class, scientists-travelers, architects, artists, musicians, along with the arrival of political exiles - the Decembrists, Polish revolutionaries.

According to some researchers, amateur theater club for performing arts in Minusinsk was organized in the late 70's of the 19th century [7, p. 153]. It was the first theater group throughout southern Siberia. Later it received a very traditional name for its time - the Minusinsk Literary, Musical and Dramatic Society or the Society of Lovers of Dramatic Art. By the end of the 19th century, similar Societies of Dramatic Arts existed in Krasnoyarsk, Omsk, Tomsk, and Irkutsk. At stages of various clubs and noble assembles, professionals and amateurs of music and theater staged Russian and foreign drama, comedy, opera, vaudeville, operetta. They also conducted literary and musical evenings, concerts, often providing charitable assistance to libraries, schools, museums, etc.

The Minusinsk Literary, Musical and Dramatic Society and the Dramatic Society were no exception. Being the center of the best cultural forces of the city, over the years it has led multifaceted scenic and charitable activities, and enjoyed great popularity among the public. In one of the "Siberian newspaper" of 1881 there was a about Minusinsk amateur society record:

"... oftentimes in the clubhouse arranged amateur theatricals in favor of various charitable purposes, always providing full collection" [15, p. 1121-1122].

Apparently, musical and theatrical activities of Minusinsk had great importance in the development of culture of Siberia as a whole. Notes on the performances and concerts of the Minusinsk Society of Dramatic Arts, reviews, were often published in one of the best provincial periodicals 80 of the 19th century - Tomsk "Siberian newspaper". It also mentions the first known today Minusinsk play - "The Marriage of Belugin" and "Lovers curse - just amuse", performed by local actors and musicians on November, 22 in 1881.

"Last Sunday, on November, 22, by the local circle of lovers of dramatic art a performance was given in favor of the Minusinsk museum ... having very limited budget. The chronic lack of money at the box office of the museum ... prompted its founder and organizer, Mr. M-v (Martyanov $-T$ $K$.), seek help from the local circle lovers of dramatic art, repeatedly and successfully performing in the current year in the theater field, for the benefit of various charitable purposes. Circle reacted sympathetically to the proposal. The $\mathrm{M}-\mathrm{v}$ arranged a performance for the benefit of the museum, and on the last Sunday in the Hall for Nobility Meetings, a specially arranged allowed for these plays to be performed: "Marriage of Belugin" and "Lovers curse - just amuse." The performance was a great success. The main play has been performed successfully by our amateur actors; it caucused a unanimous cry of delight, on the hart of spectators and lasting applause... P. D.".

According to official data, this performance - the earliest known to us today in Minusinsk [12, c. 61-62]. Thus, the beginning of the history of the Minusinsk Drama Theater should be considered November, 22 of 1881, in spite of the generally accepted date year 1882 . Moreover, following the quotation from the text we can see that the tradition for amateur performances, concerts and dances in Minusinsk existed at least "10-15 years ago," although for some reason was somewhat weakened in the early 80s. In one of the "Siberian newspaper" in 1881, the following thing was written:

"Indifference and carelessness ... of Minusinsk society in urban well fare appears most striking now in the maintenance and support, a social club, or so-called Minusinsk noble "Assembly" closing next year for lack of funds. In previous years, ten or fifteen years ago, our club was assiduously maintained and visited during the holidays, there were both "noble" and "not honorable" men without distinction in class and social position were welcomed. On Sundays the club was always full because any man, especially a family man, did not miss a chance to have some fun together once a week in its noble assembly. This is not to be confused by the presence of high-ranking people in bureaucracy finance who often took the most active part in games and dances of common mortals. Quite often in the clubhouse, amateur performances were arranged for various charitable purposes, always providing full collection. In recent years, due to various troubles, and in particular as a result of the machinations and intrigues of the former foreman of the Assembly, the club began to fade ... [15, p. 1121-1122].

Nevertheless, on the eve of 1882 , this problem was solved. In №1 of the «Siberian newspaper» January 3, 1882 we read the following: "... one of these days, the local police officer and some officials from the citizens, gathered 
together, the remaining members of the congregation and many other ordinary people - not members to discuss about" to be or not to be the next year Assembly. Having examined all the reasons and misunderstandings, being a detriment to the club's interest, we came to the conclusion that it is necessary for the Assembly "to be" [16, p. 11].

Thus, we can say with certainty that the theater life in Minusinsk began to take shape since the early 70 of the XIX century within the framework of the urban social club - the club of the "noble" Assembly on the stage of which, as can be seen from the quoted text, a certain cultural program was carried out every Sunday. Apparently, those were performances and concerts arranged by "circle of fans of Dramatic Art" as well as very popular at that time among the people playing and dancing. Visitors of the Assembly were "noble" and "not noble" men officials, tradesmen, peasants, artisans and, of course, the intelligentsia.

If we compare Minusinsk at that time with other Siberian cities, judging by the rapid development of its cultural life at the end of the 19th century, its role is not much inferior to the role of the Yeniseisk province of the capital - the city of Krasnoyarsk, as well as other major foci of Siberian culture Irkutsk, Tomsk, Omsk. In many respects, it was ahead of a number of small peripheral cities. This is also indicated by other researchers. For example, in I.E. Shadrina, we read: "Yet at the end of last and the beginning of the 20th century, along with the cities of Irkutsk, Tomsk, Minusinsk is becoming one of the theatrical centers of Siberia. The city began to be visited by professional theatrical troupes of wandering through Russia and Siberia"[12, p. 65]. E.V. Prygun also writes about Minusinsk as one of the major cultural centers: "... in the last quarter of the XIX century in the nine largest cities in Siberia - Irkutsk, Krasnoyarsk, Tomsk, Tobolsk, Omsk, Tyumen, Barnaul, Yeniseisk and Minusinsk - already toured artistic troupes, rapidly developed activity of lovers of dramatic art. There "was not a theater or any other stage" in such cities as Achinsk, Kansk and others for much longer time" [10, p. 230-231].

In general, the formation of theatrical business in the Krasnoyarsk region was not easy. In the capital of the province - Krasnoyarsk's first theater building was only built in 1874, in the Ostrog scuare. "The building of the theater was used by city authorities for carrying out masquerades. Local amateur dramatic art performances were put on this stage. Also, touring troupes and individual actors performances took place on that stage" [10, p. 229]. However, there wasn't a permanent city theater company for a long time. This is confirmed by the data of the statistical report of the Yeniseisk provincial administration from 1885 about the presence of theaters in the cities of the Yeniseisk province. Regarding Krasnoyarsk, it says "there is a theater in which to date there's no permanent troupe of actors and entrepreneur. Plays are performed by the visiting artists and sometimes lovers from among the residents of Krasnoyarsk give performances for charity. There are three Assemblies in the city: social, vocational, military. And there are no private rooms" [4].
In the town of Yeniseisk to the reporting year, there was a theater, but without the constant entrepreneur. About Minusinsk in Yeniseisk provincial administration report was said that there were no theaters "In the city... there was country station, where sometimes in the summer time temporary stages were organized " [see: ibid].

In our opinion, this information is not reliable. The city of Minusinsk really did not have its separate theater building in 1885. During the summer, performances and concerts were held in the garden or in the open air. However, one cannot say that until 1885 , when the report was written that the musical and theatrical activities of Minusinsk District capital was limited to suburban station, "where sometimes in the summer stages were held." Playbills and cited above passage from the "Siberian newspaper" for 1881 clearly show that already in the early 80's of the 19th century the performances on the stage of the hall of the noble public Assembly were held regularly, at least "once a week" (on Sundays), and its program included not only performances, but also concerts, literary and vocal evenings, games, dances, arranged by the society of lovers of scenic and musical art to the citizens [15, p. 1121]. Moreover, in the Minusinsk posters for the $1882-1883$ were given accurate performances and concerts dates related to the early spring (March 27) and late fall (28 November), which contradicts to the report allegations about "summer" borders of the city theater season.

The earliest theatrical poster, preserved in the N.M. Martyanov museum dates back to the November 28, 1882. On this day drama "Guilty without Guilt" by N.N. Elizarov and joke-vaudeville "Daughter of Russian actor" by P.I. Grigoriev (1806-1871) was staged at Minusinsk stage in favor of urban Library by the Society of Lovers of Dramatic Arts, renowned playwright and actor in Alexandriysk Theatre, the author of more than 70 comedies and vaudevilles). The poster was in handwriting:

With the permission of the authorities November 28,1882 In Minusinsk

By Lovers of Dramatic Arts will be given performance For the benefit of Minusinsk Public Library "Guilty without Guilt"

Drama in a 4-xi acts and 5 scenes op. by Elizarov. Characters:

Maxim Yeremeyevich Chukushin (merchant) Martha Sofronovna (his wife) Alexey Nastya

Vera (niece of Chukushin)

Ustinya Mironovna Salov (matchmaker)

Peter Vasilevich Cheremov

Lyudmila Akskopevna Vyzhina Silin (the merchant's son)

Philemon Zakharych Ruchkin (lawyer) Cheremov's Valet

Stepanida (Vohzhin's cook)
I.M. Bazhenov

A.E. Benediktova

S.S. Hozinsky

N.A. Ivanova

N.V. Frankovskay

L.V. Lyatorovskaya

M.P. Popov

E.K. Malinina

N.Z. Yartsev

M.A. Kuhn

F.S. Lyapidovsky

A.I. Ryazanova
Finally:

"Daughter of Russian Actor"

Joke-farce in one act.

Characters: 
Mikhail Vasilyevich (old actor)

Vera (his daughter)

Akaky Akakievich Ushytsya

Katerina (maid)

Beginning necessarily at $7 \mathrm{pm}$.

M.P. Popov

E.K. Malinina

F.S. Lyapidovsky

A.I. Ryazanova

Price per seat: 1 st, 2 nd, 3 rows - 3 rubles, 4 th, 5, 6 and 7 - 2 rubles, 8, 9, and 10 th -1 rub... Tickets are available in the meeting at Arthur.

The program of cultural activities in Minusinsk, as a rule, was always busy. Often, in the same evening, the audience could be offered 2-3 different genres of performance, divertissement, and in conclusion, "to pasture cows" (up to morning the dawn) dances. From 1880 - 1890 in the Minusinsk stage were set: the drama "Beveled flower or a song of grief," "The Forgotten Manor" by I.V. Shpazhinsky, "Tainted Life" by Chernyshev, vaudeville "vice-uniform" by V.A. Karatygin, "Wife for rented", "Old mathematician or expectation of a comet in the provincial town", "the theater and at the wedding" with singing, comic dance and ballet to the music of Jacques Offenbach, Charles Lecocq, operetta "Would not it be a blessing but misfortune helped by Erlanger and more [1].

Apart from the fact that in the 19th century drama, vaudeville, comedy - almost all had a musical accompaniment, often after the main part of the play, the audience could hear a "Divertissement". Usually, it was a sequence of several small pieces of music, sometimes interspersed with reading stories and poems. Basically, it was the Russian folk songs and romances. For example, in May 1891, in conclusion of the music and theater evening, sounded as a divertissement: the poem by V.S. Likhachev, "Divide", the song "Forgot You" (by A. Oppel, Russian folk song "Kalinka" often the presence of Divertissement in the posters was mentioned only indirectly, for example. "Divertissement, consisting of reading poems, scenes, stories and performaning songs and couplets "or simply specified the names of performers [see: ibid].

As a rule, Divertissement pieces performed the same actors as the repertoire of the main stage of the program, but endowed with the special, music (and literary) talents. In the period under review, the capital of Minusinsk District in music Divertissement often involved: Cherniavsky, Yaroslavtseva, Lenin, Lazarev, Betipazh, Dol'sky, Varlamov and others.

\section{N.Z. YARTSEV - AN OUTSTANDING REPRESENTATIV OF THE MUSICAL AND THEATRICAL LIFE OF THE PRE- REVOLUTIONARY MINUSINSK}

Today one can't imagine the musical and the cultural life of the town of Minusinsk in the late 19th - early 20th centuries without Nicholay Zakharovich Yartsev, an outstanding musician, actor and director. He was also the founder of the Minusinsk Drama Theater, the regent of the Minusinsk Savior Cathedral and the head of the City Choir. Yartsev was born in the Yeniseisk province within the hereditary priestly family around 1861. According to archive documents, in the first half of the 19th century, the Yartsevs from generation to generation were priests and deacons of the Minusinsk district. In one of the archival documents, dated back to the year of 1865 (which is the earliest document that we found), regarding the great-grandfather of Nicholay Zakharovich - Varpholomey Anempodistov Yartsev, said: "the priest's son, was born in the Yenisei province of the Minusinsk District in the village of Askiz studied at the Yeniseisk religious school ... including note singing "[5, p. 14-15].

Most likely, the Yartsev's activities in the field of music, church and performing arts in Minusinsk started in 1878. His education very likely became the prerequisite for creative activity in addition to his natural abilities and talents (Yartsev, according to the memoirs of contemporaries, had a rare perfect pitch). In particular, it is known that the future famous director and regent of the Saviour Cathedral graduated from Tomsk Theological College, where he took a full course of studies [17, p. 2].

If we look at the history of the Tomsk spiritual school of the time, when Yartsev was studying there, it becomes clear that along with numerous educational and ecclesiastical subjects, going to church every day and singing was an integral part of the curriculum. In addition to the educational process, the children took part in various cultural events: Christmas, Easter, literary and vocal evenings and so on. The evening programmers were much varied and interesting. For the evenings, the school's large premises were prepared and decorated. Children read poems of religious and moral content sang spiritual songs in a mixed choir of students of the 2, 3 and the 4 classes, dramatized poems, playing a musical instrument ... "[9, p. 295].

Nicholay Zakharovich was both an actor and the director of the Minusinsk theatre for over 45 years. The Literary, Musical and Dramatic Society, a member of which he was, staged at the Minusinsk scene different kinds of theater art, such as opera, vaudeville, operetta, drama, comedy, organized literary and vocal evenings and concerts. The earliest theater poster preserved is dated back to the 28th of November, 1882. On this day on the stage of the theater, the drama "Guilty without Guilt" by N.N. Elizarov and jokevaudeville "The Daughter of Russian actor" by P.I. Grigoriev were performed in favor of the Minusinsk City Library Lovers of the Dramatic Arts Society. In the play "Guilty without Guilt", Yartsev played the role of the young merchant's son Silin.

According to the Yartsev's younger contemporary, an actor and the director of the Minusinsk theater Shmykov Ivan Petrovitch, when a young man, Nicholay Zakharovich showed outstanding abilities to performer young heroes ... he had a good voice and exceptional hearing [14, p. 3].

There are posters preserved, according to which Yartsev also took part in city concerts. Thus, the earliest of them refers to the literary and musical evening "in favor of the Cabinet of teaching aids", held in Minusinsk in March 1883. In the I-st part of the evening F.L. Dolzhnikov and N.Z. Yartsev performed as a duet the song "Swimmers" by A.E. Varlamov, in the second part a "comic song" was performed by Yartsev.

We note that, in addition to Yartsev, many other prominent people participated in shows and concerts of 
Minusinsk. Among them were - Elena Konstantinovna Malinina, the wife of N.M. Martyanov, the founder of the Minusinsk Museum of Local History; the chairman of the Minusinsk Literary, Musical and Dramatic Society Olympiada Aleksandrovna Volkonskaya, Timofey Nikolaevich Saylotov - the son of the Decembrist Nikolai Alexandrovich Kryukov, a musician and a teacher of singing, the leader of the high school choir and many others.

Not only by numerous theater posters, mentioning his name, but also petitions, written by Yartsev in order to get the permission of the Minusinsk District Judges (at the main place of work) to take part in an amateur performance, show the Yartsev's active participation in the musical and theatrical life Minusinsk [2].

According to our estimate of about 50 years, Yartsev, indeed, had done a lot for it, having spent on this field. The appreciation of Yartsev's achievements is reflected. In the article of the local city newspaper, inviting citizens to celebrate the anniversary of forty-five years of stage work of the venerable director - on October 29th 1922. There, among other things, the following was stated:

«... The name of Nicholay Zakharovich is well known to the Minusinsk inhabitants interested in scene, theater and art in general. The venerable hero of the day has dedicated his life to serving art and did very, very much for the formulation and development of the theater in Minusinsk. Suffice it to say, most of local artists are his students and the theater building itself with its equipment exists owing to his work...».

If we take into account the fact that, in 1922, Yartsev celebrated the 45th anniversary of his work. We can deduce that the beginning of his theater life can be dated to 1877 1878. There is no doubt, that Yartsev worked as the director of the Minusinsk lovers of dramatic art Society already in 1880, and, as he himself claimed, for 30 years he did it absolutely free of charge, being paid "of 10 rubles and more for the play" only since 1910 .

In 1916 at the meetings of the Literary, Music and Drama Society the Yartsev's name as that of a famous Minusinsk director is mentioned again: "The General Meeting of Literary and theatrical and musical Society was held on November 23 this year. Olympiada Aleksandrovna Volkonskaya was elected as a chairman. The Assembly has officially hanked the permanent director of the Society Nicholay Zakharovich. It should be noted that Yartsev's services to the Society are quite considerable [8].

The recollections about his director activities by Georgy Sobetsky, a younger contemporary and one of the artists of the Minusinsk theater, are also interesting. In 1927, he wrote to the Minusinsk department of Artists Union: "... my attention was especially attracted by the performances under direction of Yartsev Nicholay Zakharovich. In these performances, a firm hand of their director and the complete artistic decoration were always notable. Having lost his sight, director Yartsev still gave the right tone to play and pointed staging correctly due to his musical ear. The troupe was disbanded in 1921, but comrade Yartsev continued directing a team of professional artists in 1922 and 1923, continuing to stage performances "(from the copies of the documents, courteously put at the author's disposal by L.P. Tschaschina, the researcher from MGA, the originals of which were kept at the Minusinsk Pension fund and to the present time, for the period given, may have been destroyed).

The upper time boundary of the Yartsev's stage work is difficult to determine. We only know that the jubilee year was not the last one. In 1923, the next year after the 45-year - creative anniversary of the director, at the meeting of the Board of the Workmen Union and members of the cultural and educational Commission the following things were confirmed: "a) to organize a drama group under the rule of an alliance with one paid position of a director; b) to invited Yartsev Nicholay Zakharovich as a director... c) to pay the director 110000 rubles according the 15-th gradeas a highly experienced instructor.

I.P. Shmykov, who appeared on the scene of Minusinsk hardly before 1923 - 1924 mentions Yartsev as a director in the last three years of his life: "In my youth I was lucky to take part in several performances by Yartsev. I got to the heart of his instructions and, while rehearsing, tried to perform them more accurately, gratefully accepting his lessons and advice "[14].

Another important area of the Yartsev's creative work was choral singing. According to our minimum estimates, Nicholay Zakharovich had been occupying the post of the regent of the Minusinsk Savior Cathedral for not less than 17 years - from 1910 to 1927 , until the end of his life.

Old residents memories can be considered the real evidence. Of the above, mentioned actor and director Ivan Petrovich Shmykov, who participated in the last Yartsev's performances is considered. In one of his articles about Nicholay Zakharovich, he wrote: "Nicholay Zakharovich was the regent of the Cathedral Choir. Under his leadership this choir often took part in concerts of the theater. Musical and Dramatic Society, including choir, was led by the leading actress of the drama theater - O.A. Volkonskaya, who was also the chairman of the Society. The concert program included music by famous Russian composers, such as Tchaikovsky, Bortniansky, Gretchaninov, Borodin"[14].

In 1924, at the age of about 63 years, Yartsev lost his sight. However, it did not become an obstacle to his future activities. According Shmykov, "when being blind, he organized the city choir, which was attended by the exiles doctor Golubkov and Woytsekhovsky. «The city choir under the control of N.Z. Yartsev was highly respected. Sometimes we had to wonder, how the "brave blind man" (these words, crowning the head of the choir, were the tribute of its members) could manage polyphonic team, how could he sensitively distinguish counterfeit notes and stop the sound of the choir knocking the fork". Further: "After rehearsals we with special loveied N.Z. Yartsev to his apartment. He walked briskly and defined right the street sounds, surprising us with his perfect of hearing "[ibid: see].

At the old city cemetery Minusinsk, to the left of the altar of the half-destroyed Sretensky church, in 20 meters from it, 
there is the Yartsev monument, established in 1927 - the year of his death. One of the epitaphs on the monument eloquent reads: "A marvellous blindman, the director, choir director, the founder of the Minusinsk theatre Nicholay Zakharovich Yartsev". On the one side of the monument, under the words "His covenant: Sing to God, sing, sing reasonably" there are the others which do not require any comment: "With you the last chord of the famous Cathedral Choir has stopped".

How great and irreparable for the citizens the loss was, the following words, carved on the back of the gravestone, indicate:

"Your orphaned chicks bring

The last gift to You

And Your bring the last gift to You

Your loving singers carry away the sorrow of their soals".

\section{CONCLUSION}

The historical merit of N.Z. Yartsev in the development of musical and theatrical life of pre-revolutionary Minusinsk is great. Thanks to his activities a solid foundation for the development of diverse artistic life in the city began to form in the 30-s of the XIX century by modern standards, the provincial, but its role in the development of culture in the Eastern Siberia - is very significant.

\section{REFERENCES}

[1] A series of posters (performances, evenings held in Minusinsk from 1889 to 1892), Minusinsk museum of local lore after N.M. Martyanov, VF-513, d. 1-24.

[2] Asafiev B. V., "The Russian music", L.: Music, 1979.

[3] Averin V. A., Gavrilova L. V., Vanyukov E. A., Elovskaya N. A.; Efimova I. V., Lavrusheva L.G., Ponomarev V. V., "The musical culture of Krasnoyarsk", V. 2, Krasnoyarsk, 2009.

[4] Collection of information on existing in the Yeniseisk province theaters, clubs and private rooms in 1885, GAKK, F-595, op. 2, d. 792.

[5] Formulary list of the service-manager Minusinsk District Court Provincial Secretary Nicholay Zakharovich Yartsev, MGA, f. 81, op. 1, d. 2680, p. 13.

[6] Information about the Church and its staff for 1862 - 1871, UstAbakan, St. Nicholay Church. - GCU RKh "National Archives," p. I16, op. 1, d. 9, p. 14-15.

[7] Kovalev V. A., Ermolaeva L. N, Shadrina I. E, "Minusinsk", Krasnoyarsk: Bk. Publishing House, 1986., 183 p. (City of Krasnoyarsk region).

[8] Minusinsky vestnik, 1916, no. 26, p. 2.

[9] Petrov E., "History of Tomsk. Spiritual School Spiritual education in Siberia: history and modernity", conference materials, Tomsk, October, 2008. Tomsk Theological Seminary, 2009, p. 292-311.

[10] Prygun E. V., "The musical culture of Krasnoyarsk: 1628-1920", Krasnoyarsk State Academy of Music and Theatre, Krasnoyarsk, 2009, 456 p.

[11] Rest in peace, after the name. Minusinsk necropolis. Book One. Minusinsk, information-publishing agency "Hope and We", 2009.

[12] Shadrina I. E., "Names connecting thread: the history of Minusinsk theater in persons", Krasnoyarsk: Bukva, 2008, 424 p.

[13] Shindin B. A. and others, "The musical culture of Siberia. The in 3 V.V. V.2. The musical culture of Siberia by Ermak hikes before the
October Revolution. Book 1. Musical culture of Siberia since Ermak hikes (in 1582) to the peasant reform of 1861, Com. Novosibirsk region Administration; Novosib. state. Conservatory by M.I. Glinka, Novosibirsk, 1997, 432 p.

[14] Shmykov I. P., "On the 100th anniversary of the theater Minusinsk", Iskra Ilyich, 1982, October 10, p. 3.

[15] Siberian newspaper, 1881 , no. 40.

[16] Siberian newspaper, 1882, no 1.

[17] The Personal File of the Minusinsk District official Yartsev. The Formulary List of service of the collegiate recorder Nikolay Zakharovich Yartsev. Officer post Minusinsk head clerk of the District Court, MGA, f. 81, op. 1, d. 2680, p. 1-17. 